Dept. of Biochemistry and Nutritional Deficiency Diseases.

Animal Health Research Institute, Assiut Lab.

\title{
SOME HEMATOLOGICAL AND BLOOD SERUM BIOCHEMICAL INDICES ASSOCIATED WITH RESPIRATORY AFFECTIONS IN CAMELS
}

(With 4 Tables)

By

EMAN M.A. EL-NASER and G.F.A. KHAMIS

(Received at 15/8/2009)

بعض المؤشرات الاموية والبيوكيميائية في سيرم الام المصاحبة للاصابات التففية في الجمال في فيرم

ابيان محد عبل/(لناصر ، جابر فرغلي أحد خمبس

أجريت هذة الدر اسة على عدد 40 من الجمال بمحافظة اسيوط منها عشرة من الجمال السليمة الجيا

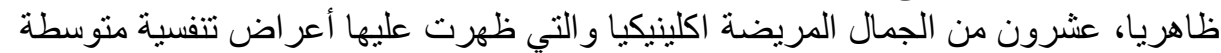

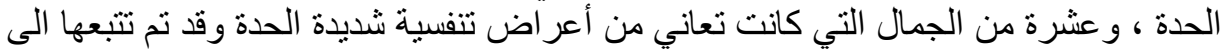

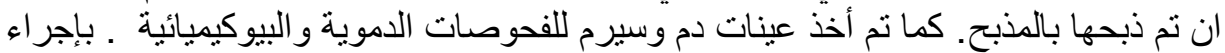

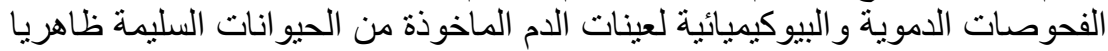

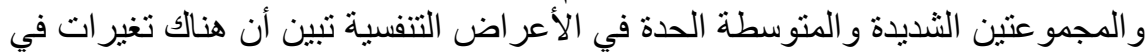

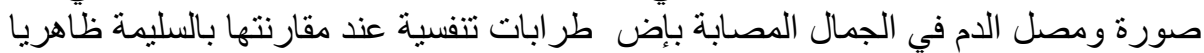

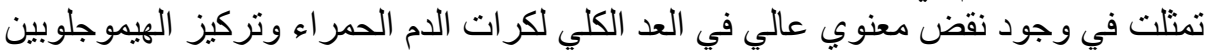

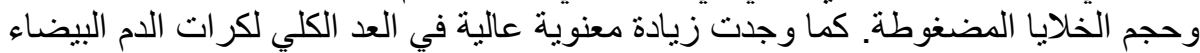

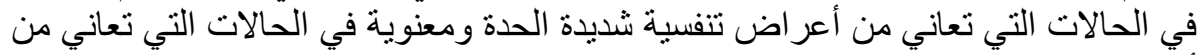

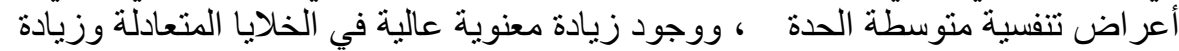

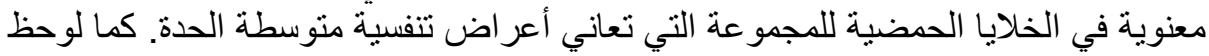

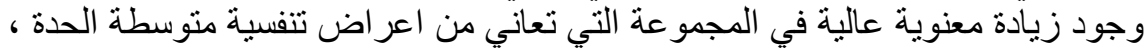

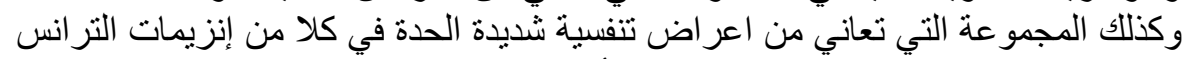

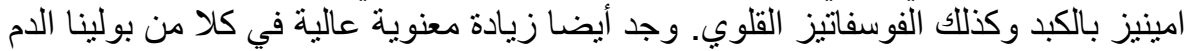

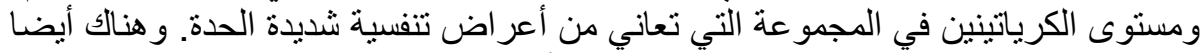

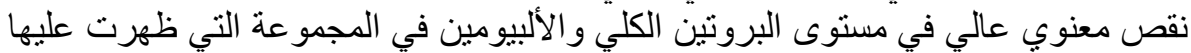

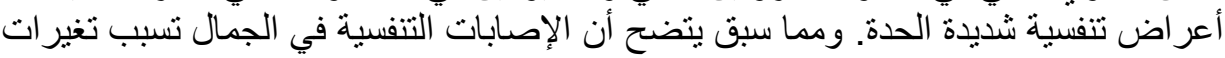
معنوية في صورة الدم وكذلك في وظائف كلا من الكبد والكئ الكلي. 
This study was carried out on 40 camels in Assuite governorate, 10 of them apparently healthy, 20, suffering from moderate respiratory signs and 10 cases suffering from severe respiratory signs. The animals were followed until slaughter and post mortem examination showed severe congested lungs. Blood samples were collected from the clinically healthy and diseased groups of camels. Two blood samples were obtained from each animal, one as a whole blood and the other in the form of blood for obtaining clean non - haemolysed serum .Hematological studies revealed the presence of high significant decrease in total erythrocyte count, hemoglobin concentration and packed cell volume in diseased camels when compared with clinically healthy ones. There was also a high significant increase in total leucocytes count, significant increase in neutrophile, and eosinophil cells were recorded in diseased cases. The study of biochemical parameters revealed high significant elevation in the values of AST, ALT, and ALP activities, also in blood urea and serum creatinine and presence of high significant decrease in the levels of total protein and albumin of diseased cases. From the previously mentioned data, it was clear that respiratory affections in camels cause significant changes in blood picture and liver and kidney functions.

Key words: Camel, hematology, biochemistry, respiratory affections.

\section{INTRODUCTION}

The camel plays a much more important role in the economy, due to the numerous advantages. It has over other livestock species in terms of work capacity, milk and meat production and environmental conservation (Wilson, 1984; EL-Gayoum, 1986; Higgin, A.J. and Kock, R.A, 1986; Werrnery, 1992 and Bekele, 1999). Beside the significant tolerance to water shortage in desert areas which constitutes majority of Egyptian land. Camel rearing might have the potential to become of pivotal economical importance (Ramet, 2001 and Seleim et al., 2009). Despite camel's importance, the animal has been largely neglected by international agencies and local governments as regards improvements of its health and productivity, concerted efforts as well as intensive investigation on their diseased problems that gets to be boosted for the greater potentials of camels production (Bekele, 1999 and Seleim et al., 2009). Rearing systems, stress factors, climatic changes, unhygienic conditions, sudden changes in feed and low level herd health status were 
stated as predisposing factors to respiratory diseases of domestic animals (Seleman and Wiseman, 1983; Schwartz et al., 1992 and Costa et al., 1998). The camels examined in this study were mainly those owned by the local people and which are involved in farm work, transportation, domestic house hold work, or kept as source of milk and meat. Hematological and biochemical analysis of blood can often provide valuable information regarding health and sickness of animals (Rezakhani et al., 1997; Osman and Al-Busadah, 2000; and AL-Busadah, 2007). The respiratory affections were found to act directly on the lung, liver and kidney cells altering their physiological mechanisms and indirectly affect the serum biochemical parameters (Osman and AL-Busadah, 2000 and AL-Busadah, 2007).

The aim of this study was to investigate the hematological and serum biochemical changes accompanied with respiratory affections in camels. Respiratory affections in camels were always accompanied most of the time with heavy economic losses. It was estimated that the losses was due to loss of productivity as well as the heavy costs of compulsory medication or vaccination required for the infected animals (Manoharan et al., 1997; Srivastava, 1998 and Singh and Jayprakasan, 2001).

\section{MATERIALS and METHODS}

\section{1- Animals:}

The present study was carried out on 40 camels aged from 3-11 years. Ten of them were suffering from severe respiratory disorders including rabid breathing, mucopurulent discharge ,severe congested mucous membranes and pyrexia and followed up until slaughtered in slaughter house where they showed sever congested lungs. The rest were divided in to two groups, 10 apparently healthy and 20 diseased camels showed signs of respiratory troubles including rapid breathing, moist rales, congested mucous membranes, dysponea and pyrexia.

\section{2- Blood samples:}

Blood samples $(10 \mathrm{ml})$ were collected from jugular vein in two sets, one containing EDTA and the other without EDTA for serum separation.

\section{3- Determination of hematological parameters:}

Determination of blood picture including hemoglobin concentration $(\mathrm{HB})$, erythrocyte count $\left(\mathrm{RBC}_{\mathrm{S}}\right)$, total and differential leukocyte counts $\left(\mathrm{WBC}_{\mathrm{S}}\right.$ and $\mathrm{DLC}_{\mathrm{S}}$ ) as well as packed cell volume (PCV) according to Jain (1986).

\section{4- Determination of biochemical parameters:}


Clear non haemolysed sera separated and transferred to sterile vials, used for determination of serum proteins assay (total protein, Albumin, Globulins, and A/G ratio mathematically) using reagent kits supplied commercially (STANBIO laboratories), and processed according to Young, (1975) and Henry, (1976).

Determination of Aspartate amino transferase (AST), Alanine amino transferase (ALT) and Alkaline phosphatase (ALP) activities, using reagent kits supplied commercially by (STANBIO laboratories) and processed according to Szasz, (1976).

Determination of blood urea nitrogen (BUN), and blood serum creatinine were carried using reagent kits supplied commercially (STANBIO laboratories) and processed according to Young, (1975).

NB: All parameters were measured spectrophotometry.

\section{Statistical analysis:}

Statistical analysis of the obtained data was done by means of computer statistical performance (Spsswin, 1995). Means, standard error and significant of variance were statistically achieved.

\section{RESULTS}

All hematological and blood serum biochemical results were illustrated in Tables (1, 2, 3 and 4).

Table 1: Mean values of some hematological parameters in apparently healthy and respiratory diseased camels.

\begin{tabular}{|l|c|c|c|}
\hline Animals groups & $\begin{array}{c}\mathrm{RBC}_{\mathrm{S}} \\
\left(10^{12} \mathrm{~L}^{-1}\right)\end{array}$ & $\begin{array}{c}\mathrm{Hb} \\
(\mathrm{g} / \mathrm{l})^{-1}\end{array}$ & $\begin{array}{c}\mathrm{PCV} \\
(\%)\end{array}$ \\
\hline $\begin{array}{l}\text { Apparently healthy } \\
(\mathrm{n}=10) \text { control }\end{array}$ & $10.18 \pm 0.64$ & $14.39 \pm 0.41$ & $31.10 \pm 1.33$ \\
\hline $\begin{array}{l}\text { Moderate respiratory } \\
\text { diseased camels (n=20) }\end{array}$ & $9.55 \pm 0.35$ & $13.64 \pm 0.26$ & $30.25 \pm 0.57^{*}$ \\
\hline $\begin{array}{l}\text { Severe respiratory diseased } \\
\text { camels (n=10) }\end{array}$ & $6.85 \pm 0.10^{* * *}$ & $10.66 \pm 0.16^{* * *}$ & $23.60 \pm 0.16^{* * * *}$ \\
\hline
\end{tabular}

Each value represents the means \pm standard errors, Significance compared to control: $\left\{{ }^{*} \mathrm{P}<0.05,{ }^{* *} \mathrm{P}<0.01,{ }^{* * *} \mathrm{P}<0.001\right\}$ 
Table 2: Mean values of some hematological parameters in apparently healthy and respiratory diseased camels.

\begin{tabular}{|l|c|c|c|c|c|c|}
\hline \multicolumn{1}{|c|}{ Parameters } & $\begin{array}{c}\mathrm{WBC}_{\mathrm{S}} \\
\left(10^{9} \mathrm{~L}^{-1}\right)\end{array}$ & $\begin{array}{c}\text { Neutrophil } \\
(\%)\end{array}$ & $\begin{array}{c}\text { Eosinophil } \\
(\%)\end{array}$ & $\begin{array}{c}\text { Basophil } \\
(\%)\end{array}$ & $\begin{array}{c}\text { Monocytes } \\
(\%)\end{array}$ & $\begin{array}{c}\text { lymphocytes } \\
(\%)\end{array}$ \\
\hline $\begin{array}{l}\text { Animals groups } \\
(\mathrm{n}=10) \text { control }\end{array}$ & $9.18 \pm 0.68$ & $54.6 \pm 0.13$ & $8.72 \pm 0.15$ & $0.13 \pm 0.11$ & $1.62 \pm 0.12$ & $31.02 \pm 0.12$ \\
\hline $\begin{array}{l}\text { Moderate } \\
\text { respiratory diseased } \\
\text { camels (n=20) }\end{array}$ & $12.32 \pm 0.37^{*}$ & $52.0 \pm 0.12$ & $14.41 \pm 0.13^{*}$ & $0.18 \pm 0.14$ & $1.02 \pm 0.1$ & $29.4 \pm 0.11$ \\
\hline $\begin{array}{l}\text { Severe respiratory } \\
\text { diseased camels } \\
(\mathrm{n}=10)\end{array}$ & $16.46 \pm 0.50^{* *}$ & $60.0 \pm 0.14^{* *}$ & $9.11 \pm 0.17$ & $0.33 \pm 0.16$ & $1.26 \pm 0.1$ & $30.00 \pm 0.14$ \\
\hline
\end{tabular}

Each value represents the means \pm standard errors, Significance compared to control $:\left\{{ }^{*} \mathrm{P}<0.05,{ }^{* *} \mathrm{P}<0.01\right\}$

Table 3: Mean values of some hematological parameters in apparently healthy and respiratory diseased camels.

\begin{tabular}{|l|c|c|c|c|}
\hline Animals groups & $\begin{array}{c}\text { Total } \\
\text { protein }\end{array}$ & $\begin{array}{c}\text { Albumin } \\
(\mathrm{g} / \mathrm{d} 1)\end{array}$ & globulins & $\begin{array}{c}\text { ALG } \\
\%\end{array}$ \\
\hline $\begin{array}{l}\text { Apparently healthy } \\
(\mathrm{n}=10) \text { control }\end{array}$ & $7.22 \pm 0.17$ & $3.50 \pm 0.02$ & $3.56 \pm 0.14$ & $0.98 \pm 0.04$ \\
\hline $\begin{array}{l}\text { Moderate respiratory } \\
\text { diseased camels }(\mathrm{N}=20)\end{array}$ & $6.55 \pm 0.10^{*}$ & $3.0 \pm 0.02$ & $3.71 \pm 0.14$ & $0.80 \pm 0.03$ \\
\hline $\begin{array}{l}\text { Severe respiratory } \\
\text { diseased camels }(\mathrm{n}=10)\end{array}$ & $5.45 \pm 0.21^{* *}$ & $2.04 \pm 0.08^{* * *}$ & $3.81 \pm 0.18$ & $0.53 \pm 0.02^{* * *}$ \\
\hline
\end{tabular}

Each value represents the means \pm standard errors, Significance compared to control: $\left\{{ }^{*} \mathrm{P}<0.05,{ }^{* *} \mathrm{P}<0.01,{ }^{* * *} \mathrm{P}<0.001\right\}$

Table 4: Mean values of some hematological parameters in apparently healthy and respiratory diseased camels.

\begin{tabular}{|l|c|c|c|c|c|}
\hline \multicolumn{1}{|c|}{ Parameters } & $\begin{array}{c}\text { BUN } \\
\mathrm{m} \mathrm{mol} / \mathrm{L}\end{array}$ & $\begin{array}{c}\text { creatinine } \\
(\mathrm{mg} / \mathrm{d} \mathrm{L})\end{array}$ & $\begin{array}{c}\text { ALT } \\
(\mathrm{u} / \mathrm{I})\end{array}$ & $\begin{array}{c}\text { AST } \\
(\mathrm{u} / \mathrm{I})\end{array}$ & $\begin{array}{c}\text { ALP } \\
(\mathrm{m} . \mathrm{m} . \mathrm{u} / \mathrm{L})\end{array}$ \\
\hline $\begin{array}{l}\text { Animals groups } \\
\text { healthy } \\
(\mathrm{n}=10) \text { control }\end{array}$ & $21.15 \pm 0.87$ & $0.81 \pm 0.02$ & $14.56 \pm 0.52$ & $30.3 \pm 1.06$ & $0.93 \pm 0.03$ \\
\hline $\begin{array}{l}\text { Moderate } \\
\text { respiratory } \\
\text { diseased camels } \\
(\mathrm{n}=20)\end{array}$ & $40.17 \pm 0.60$ & $1.23 \pm 0.04^{*}$ & $20.51 \pm 0.53^{* *}$ & $39.02 \pm 0.19^{* *}$ & $1.04 \pm 0.02^{* *}$ \\
\hline $\begin{array}{l}\text { Severe respiratory } \\
\text { diseased camels } \\
(\mathrm{n}=10)\end{array}$ & $45.98 \pm 0.59^{* * *}$ & $1.88 \pm 0.06^{* *}$ & $28.8 \pm 1.51^{* * *}$ & $42.9 \pm 0.44^{* *}$ & $1.28 \pm 0.04^{* *}$ \\
\hline
\end{tabular}

Each value represents the means \pm standard errors, Significance compared to control: $\left\{{ }^{*} \mathrm{P}<0.05,{ }^{* *} \mathrm{P}<0.01,{ }^{* * *} \mathrm{P}<0.001\right\}$ 


\section{DISCUSSION}

Dealing with the changes in the hematological parameters in diseased camels (Table, 1), there was a highly significant reduction $(\mathrm{p}<0.001)$ in total erythrocytic counts and hemoglobin concentration ( $p<0.01$ ), in the severe respiratory affected camels, while PCV showed significant reduction $(\mathrm{p}<0.05)$, in the moderate respiratory diseased camels and a highly significant reduction ( $\mathrm{p}<0.001$ ), in the severe respiratory diseased camels. These finding could be attributed to the failure of bone marrow cells and hepatocytes in utilization and the reduce of hemoglobin synthesis resulting in inhibition of erythropiesis during respiratory affections ( Kaneko et al., 1997 ) These results agreed with those recorded by Monaa, (1990) and Baraka et al. (2000).

Table 2 showed significant increase $(\mathrm{p}<0.05)$ in TWBs and eosinophil in the moderate respiratory diseased camels, while highly significant increase occurred $(\mathrm{p}<0.01)$ in Twbes and neutrophils in the severe respiratory affected camels. These findings were supported by those obtained by Parape et al. (1973) and Gwazdauskas et al. (1980), who referred such hematological changes to the release of endogenous corticosteroids in response to stress which have a major role in regulating circulating concentration of leucocytes.

Serum biochemical analysis of respiratory affected camels (Table 3) elucidated a significant decrease $(\mathrm{p}<0.05)$ in total protein in the moderate diseased camels and a highly significant decrease $(p<0.01)$ in the severe diseased ones. Also showed a highly significant decrease in albumin and $\mathrm{A} / \mathrm{G}$ ratio in the severe diseased camels. These results are supported by Hassan, (1984) and Nasser and EL-sayed, (1997). These may be attributed to occurring inabilition of the liver to protein synthesis.

The respiratory affected camels showed a highly significant increase $(\mathrm{p}<0.001)$ in serum urea (Table 4$)$ and showed a significant increase in the moderate diseased camels, $(\mathrm{p}<0.05)$ and highly significant increase $(\mathrm{p}<0.01)$ in the severe diseased camels in serum creatinine level. These findings fitted closely with those of Ali et al. (1998) and Seleim et al. (2003) who referred the increase of blood urea and serum creatinine values to the increase in protein catabolism, febrile conditions, diseases causing impaired cardiac function and decreased renal blood flow as well as renal damage from any causative agents effects.

The obtained data concerning liver functions tests (Table 4) showed a highly significant elevation $(p<0.01)$ of Aspartate amino 
transferase (AST), Alanine amino transferase (ALT) and Alkaline phosphates (ALP) in both moderate and severe respiratory affected camels.

Such elevation in liver enzymes referred to the degenerative and necrotic changes of the liver following the infection and the effect of the circulating toxins. These results come in accordance with those reported by (Ali et al., 1998 and seleim et al., 2003).

Previous results and published data indicate that more detailed investigations of respiratory diseased camels are needed. Adequate hygienic measures and proper management may reduce the degree of animal exposure to disease producing agents.

Respiratory affections were accompanied with some reversible adverse effects on animal health represented by hepatic, renal dysfunction and disturbance of hematological patterns, so we can put the previously concluded points in our consideration in diagnosis and treatment of respiratory affections.

\section{REFERENCES}

AL-Busada, K.A. (2007): Some biochemical and hematological indices in different breeds of camels in Saudi Arabia. Scientific Journal of king faisal university (Basic and Applied Sciences). Vol. 8. No.1. P: 131-142.

Ali, A.A.; Mohammed, S.R.; Hafez, I.G. and Ahmed, E.K. (1998): Clinicopathological and Bacteriological studies on calves suffered from pneumonia. Egypt. J. comp. path. clinic. path. 11: (2) 59-75.

Baraka, T.A.; EL-Sherif, M.T.; Kubesy, A.A. and IIiek, J. (2000): Clinical studies of selected ruminal and blood constituents in dromedary camels affected by various diseases. Acta Vet. Brno, 69: 61-68.

Bekele, T. (1999): Studies on the respiratory disease "Sonbobe" in camels in the Eastern low land of Ethiopia. Tropical Animal Health and production, 31: 333-345.

Costa, L.R.R.; Spier, S.J. and Hirsh, O.C. (1998): Comparative molecular characterization of Corynebacterium Pseudotuberculosis of different origins. Vet. Microbial, 62: 135-143.

EL-Gayoum, S.E.A. (1986): Studies on the mechanism of resistance to camel diseases. Dissertation, Goenttingen, Heft, PP: 22. 
Gwazdauskas, F.C.; Paape, M.J.; Peerey, D.A. and Mcglliard, M.L. (1980): Plasma glucocorticoid and circulating blood leukocyte responses in cattle after sequential intramuscular injection of ACTH. Am. J. Vet. Res. 41: 1052-1056.

Hassan, M.S. (1984): Investigation on an out-break of enzootic bronchopneumonia in calves: clinical significance of blood serum proteins and electrophoretic serum protein fraction. Assiut. Vet. Med. J. 11: 177-182.

Henry, R.J. (1976): Determination of total serum protein. Clinical chemistry, Hoeber, N.Y.P: 413-415.

Higgin, A.J. and Kock, R.A. (1986): A guide to the clinical examination, chemical restraint and medication of the camel. Br. Vet. J., 140: 485-504.

Jain, N.C. (1986): Schalm,s Veterinary Hematology. $4^{\text {th }}$ Ed. Philadelphia, U.S.A, Lea and Febiger.

Kaneko, J.J.; Johan, H.W. and Michael, B.L. (1997): Clinical biochemistry of domestic animals $5^{\text {th }}$ Ed. Academic press, San Digo, London, Tokyo and Toronto.

Manoharan, S.; Jayaparakasan, V.; Pillai, R.M. and Sulochana (1997): Immunization of mice with antigens of Pasteurella Multocida of rabbit origin. Indian Vet. J. 74: 1-4.

Monaa, A.M.A. (1990): Clinical, hematological and some biochemical changes in healthy and diseased camels. Ph. D. Thesis, faculty of Veterinary Medicine. Assiut University, PP: 220.

Nasser, M.H. and EL-Sayed, R.E. (1997): Clinical, biochemical and bacteriological studies on pneumonic buffalo calves with trials for treatment. J. Vet. Med. Ass. 57: 549-566.

Osman, T.E.A. and Busadah, K.A. (2000): Effect of age and lactation on some biochemical constituents of camel blood in Saudia Arabia. J. of camel practice. 7, 149-152.

Parape, M.J.; Schultze, W.D. and Miller, R.H. (1973): Thermal stress, circulating erythrocytes, leukocytes and milk somatic cells. J. Dairy Sci.; 56: 84-91.

Ramet, J.P. (2001): The technology of making cheese from camel milk (camelus dromedaries). FAO, Animal production and health, Rome.

Rezakhani, A.; Habibadi, S.N. and Ghojogh, M.M. (1997): Studies on normal hematological and biochemical parameters of Tuurkmen camel in Iran. Journal of camel practice and research 4, 41-44. 
Schwartz, H.J.; Dioli, M. and ds, E. (1992): The one - humped camel (camelus dromedaries) in Eastern Africa; Apictorial guide to diseases health care and management. Weikersheim, Germany, Velag Josef Magraf, P: 199-203.

Seleim, R.S.; Amal, R. Tos; Sahar, R.; Mohamed; Nada, H.S. and Gobran, R.A. (2009): Elisa and other tests in the diagnosis of Pasteurella Multocida infection in camels.http: // www. Priory. com / Vet./ camels. htm.

Seleim, R.S.; Tos, A.; Mohamed, S.R.; Nada, H.S. and Gobran, R.A. (2003): Elisa and other tests in the diagnosis of Pasteuralla Multocida infection in camels. Deutcher Tropentag, Gottingen, October 8-10. Conference on international Agriculture Research for development.

Seleman, I.F. and Wiseman, A. (1983): A study of respiratory diseases of adult cattle. Ir. Vet. J. 37: 183-187.

Singh, $R$. and Jayprakasan, V. (2001): Use of different antigenic preparations of Pasteurella Multiocida in enzyme immuno assay. Indian Vet. J. 78: 379-381.

Sirvastava, S.K. (1998): Characteristics of whole cell proteins of Pasteurella Multocida serotype B6. Indian Vet. J. 75: 395-398.

Spsswin (1995): Soft war packet for statistical analysis under windows, U.S.A.

Szasz, G. (1976): Laboratory diagnosis. Clin. Chem., 15: 124-136.

Wernery, U. (1992): Dromedare, die Rennpferde Arabiens. Tierarztl. Um Schau, 47: 801.

Wilson, R.T. (1984): The camel. Longman, London and New York. P.223.

Young, D.S. (1975): Detection of serum albumin levels. Clin. Chem., 21: 244-247. (special Issue). 
Assiut Vet. Med. J. Vol. 55 No. 123 October 2009 